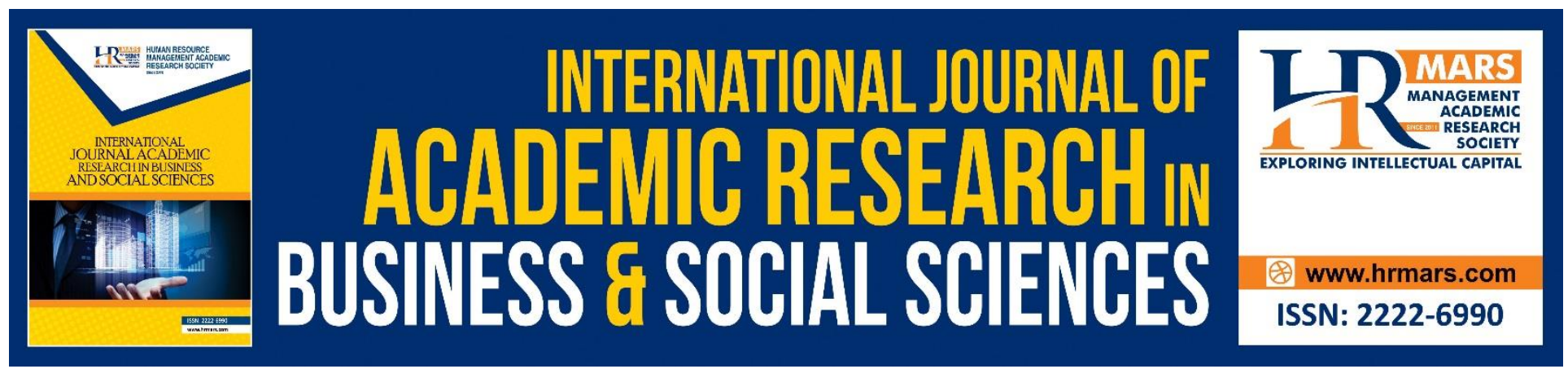

\title{
The Development of Ghazal Melayu Johor Music Composition from the 1950s till Present
}

Kamarulzaman bin Mohamed Karim, Colleen Wong, Mohd Azam bin Sulong

To Link this Article: http://dx.doi.org/10.6007/IJARBSS/v10-i9/7790

DOI:10.6007/IJARBSS/v10-i9/7790

Received: 10 June 2020, Revised: 13 July 2020, Accepted: 19 August 2020

Published Online: 29 September 2020

In-Text Citation: (Karim, Wong, \& Sulong, 2020)

To Cite this Article: Karim, K. B. M., Wong, C., \& Sulong, M.A. B. (2020). The Development of Ghazal Melayu Johor Music Composition from the 1950s Till Present. International Journal of Academic Research in Business and Social Sciences. 10(9), 425-438.

Copyright: (C) 2020 The Author(s)

Published by Human Resource Management Academic Research Society (www.hrmars.com)

This article is published under the Creative Commons Attribution (CC BY 4.0) license. Anyone may reproduce, distribute, translate and create derivative works of this article (for both commercial and non-commercial purposes), subject to full attribution to the original publication and authors. The full terms of this license may be seen

at: http://creativecommons.org/licences/by/4.0/legalcode

Vol. 10, No. 9, 2020, Pg. 425 - 438

Full Terms \& Conditions of access and use can be found at http://hrmars.com/index.php/pages/detail/publication-ethics 


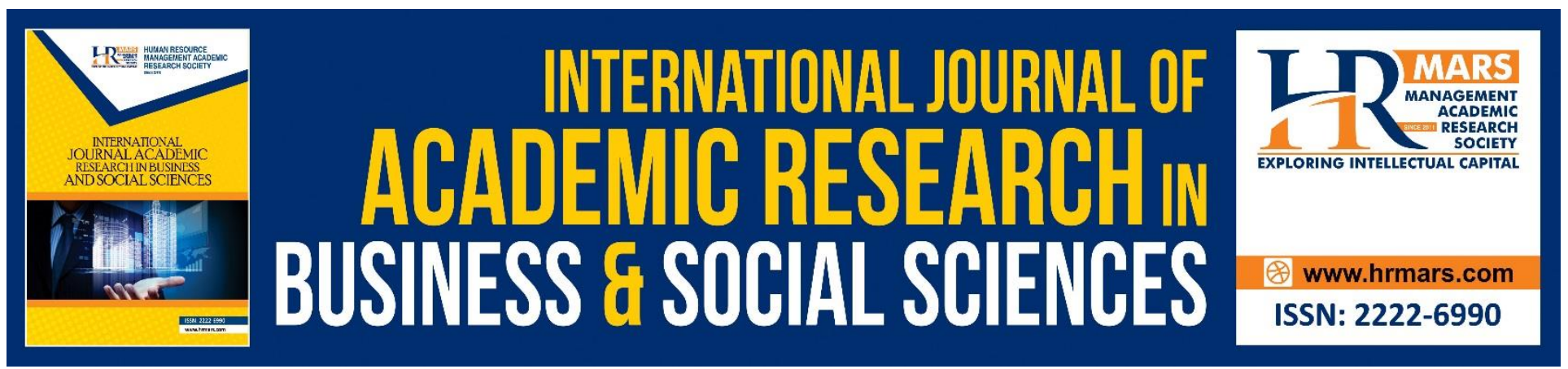

\title{
The Development of Ghazal Melayu Johor Music Composition from the 1950s Till Present
}

\author{
Kamarulzaman bin Mohamed Karim, Colleen Wong, Mohd Azam bin \\ Sulong \\ Universiti Pendidikan Sultan Idris \\ Email:kamarulzaman.mk@fmsp.upsi.edu.my,colleen@fmsp.upsi.edu.my, \\ azamdungun@fmsp.upsi.edu.my
}

\begin{abstract}
Since the emergence of Ghazal Melayu Johor music (GMJ) pioneered by Pak Lomak around the 1920s until now, there has not been any comprehensive study ever conducted on the aspects of the creation or style of composition that has ever existed. Previous GMJ music studies focused on the historical and traditional characteristics of the music and did not investigate the creativity and innovation aspects which have been developed till now. As a result, no concepts of GMJ creation which has ever been used as references and guide in the world of music since it was born till now. The first objective of this study was to examine the influence of composition in the development of GMJ music from the context of inspiration/motivation of composition and socio-culture. Secondly, summarized the style of composition that has taken place in the development of GMJ music based on the era monopolized by well-known figures. This study used comparative methodology to summarize the development happened between traditional GMJ music to date. This study used a qualitative methodology of documents analysis for (written and audio/visual recording) Ghazal Melayu Johor and interviews with leaders and Ghazal Melayu Johor music activists. The implication for this study is to provide an overview and scholarly information to readers on the Ghazal Melayu Johor Music Composition since there are no research conducted previously.
\end{abstract}

Keywords: Ghazal Melayu Johor (GMJ), Traditional Music and Music Creation.

\section{Introduction}

The term ghazal is actually very familiar in the traditional world of art in which it is often associated with poetry and music originated from Arabian, Indian and Pakistani cultures. There are even names of ghazal composers who are well known globally such as Amer Khusrou, Nusrat Fateh Ali Khan, Mehdi Hassan, Jagjit Singh, Ghulam Ali, and many more. The situation is not the same as Malay ghazal. There are still many who do not know its existence and the composers who are very successful in its development such as Pak Lomak, Ahmad Jusuh, Mokhtar Zam Zam, Kassim Taib, S. Baharom and many more. The development of GMJ's composition are worried to be deteriorating as many of GMJ's composition are not being highlighted especially the 'un-popular' compositions. 
INTERNATIONAL JOURNAL OF ACADEMIC RESEARCH IN BUSINESS AND SOCIAL SCIENCES Vol. 10, No. 9, 2020, E-ISSN: 2222-6990 @ 2020 HRMARS

Low level of appreciation for traditional music in our country today has resulted in many Malaysian traditional music, not only Malay ghazal, are forgotten and received less opportunity and wide exposure. Therefore, the process of gaining knowledge of traditional arts in Malaysia happens slowly. The construction of a concept or theory mainly needs elements of meaning and phenomena that occur in society to be used as a source of knowledge. Fewer phenomena found in the area has made it more difficult to formulate a concept of art in any contexts including the creativity of its creation.

The word 'Ghazal' comes from the Arabic language meaning to speak to women with the theme of love (Kanda, 1998, p. 4). Ghazal also means poetry of love. This poem is considered as one of the most popular types of poetry in Arab society since the age of Ignorance (Zaman, 1998, p. 143). Ghazal in Malaysia is divided into two: Ghazal Melayu Johor and Ghazal Pati in Kedah (Machfrida, 1998, p. 23). Ghazal Melayu Johor was more influenced by Hindustan while Ghazal Pati Kedah was more influenced by Arabic art. Ghazal Melayu which is synonymous with the art of southern was formerly comprised of Riau, Lingga and Singapore. The Johor government then was responsible in introducing Ghazal music to the respective provinces. However, the art of Ghazal was separately developed when there was power struggles between British and Dutch where British controlled Johor and Singapore while Dutch controlled Riau, Lingga and the whole of Sumatra.

Dato Bentara Luar Johor, Dato Mohamad Salleh Bin Perang was the person who first introduced the art of Persian Ghazal and Hindustani Ghazal to Malaya (Zaman, 1998, p. 145). During the time, Ghazal music was not yet formed like what we listen today. Melayu Asli Music was formed much earlier and became popular among royal musicians. Due to this, traditional Malay music was also experimented with musical instruments brought in from Persia and Hindustan such as Tabla, Harmonium, Sitar and Saranggi. Among the earliest traditional Malay song composed was Jalak Lenting.

The grandson to Dato Bentara Luar, Pak Lomak, or his real name Haji Musa Bin Yusof, was the person responsible in the formation of Ghazal music through compositions and performances. He had limited Ghazal musical instruments to only seven instruments: Harmonium, Tabla, Gambus, Guitar, Violin, Tamborine, and Marakas. The form of Ghazal music is composed on its own to differentiate it Melayu Asli music. Elements of Hindustani music began to be absorbed into singing techniques and instrumental techniques until a new musical identity was composed at the time named Ghazal Melayu.

\section{Recording Technology and Popular Songs of Ghazal Melayu}

This study was also based on audio recordings in the 1960s and above because only at this time the new recording technology existed in Malaya. In other words, the Ghazal composition in the 1920s to 1950 s were referred to the style of playing among Ghazal musicians in the 1960s and 70s. Thus, there might be differences in the characters of playing Ghazal due to different techniques of interpretation and expressions from musicians who were alive in the early days of Ghazal's existence.

In fact, many ghazal songs were composed without going through the process of gramophone recording. The songs were only played among the groups and only spread around the mukim or 
INTERNATIONAL JOURNAL OF ACADEMIC RESEARCH IN BUSINESS AND SOCIAL SCIENCES Vol. 10, No. 9, 2020, E-ISSN: 2222-6990 @ 2020 HRMARS

districts by the active ghazal groups. All this happened due to the development of recording technology focusing only on cities such as Johor Bahru and Muar, as well as the attitudes of the Malay ghazal artists themselves who preferred to expose their works through live performances rather than music recording.

Based on this phenomenon, popular songs of Malay ghazal is referred to songs that went through the process of recording, widely spread through mass media and often played by many other groups of Ghazal Melayu Johor.

\section{Inspiration of Composing Ghazal Melayu Johor Music}

Inspiration also known as inspirasi in Malay word means "sesuatu yg menggerakkan hati utk mencipta sesuatu (hasil seni dII)" (Pustaka, 2017) or it can be interpreted as things that moves the heart to create something. Although it is synonymous with the term 'inspiration', the source that moves something is wider, while 'ideas' are initiated by God (Pustaka, 2017). Inspiration does not only happen in the creation of art alone, but it includes a process that takes place in all of human activities.

The composition of music will always be related to the aspects of creativity and philosophy. The creativity of modern artists is not equivalent to traditional artists because they have different philosophies of composition. The features of individualism are more evident in the composition of modern music, while in traditional music, the aspects of collectiveness and togetherness are more dominant in its work. Therefore, the philosophy of Malay Ghazal has always indicated the personality of old Malay artists who were very concern with the values of unity and togetherness in their compositions which sometimes are very difficult for us to identify real composers of certain ghazal songs.

Although the new Malay ghazal was only formed in the 1920s as a result of the development of Nasib songs (Melayu Asli songs), the features of the old Malay philosophy are still evident. Thus, as time goes on to subsequent years, these features had undergone significant changes as a result of modern aesthetic values.

\section{Figures of Ghazal Melayu Johor Songs Composition}

It is undeniable that there are many figures who have contributed in the development of GMJ music from the past to the present. The names of prominent songwriters of Malay ghazal in the 1920s were dominated by Pak Lomak as the person responsible in developing Malay ghazal music and spreading it to all the colonies in Johor state including Riau and Lingga. Starting from 1950s onwards, more ghazal songwriters were born. 


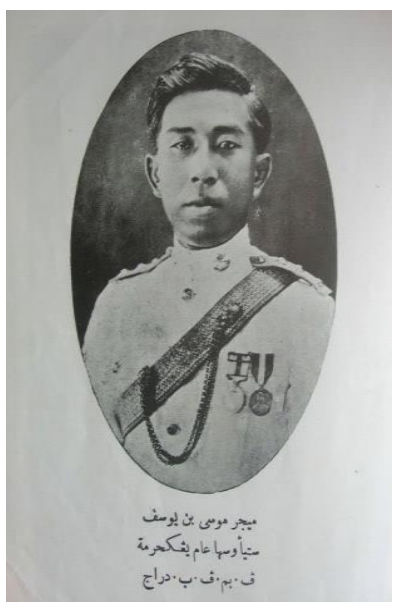

Figure 1 Pak Lomak as the Father of Ghazal Melayu Johor

To facilitate this study, several prominent figures were grouped according to the popularity level of their works often played in recordings and performances. This grouping started from the 1950s until recent as illustrated in the figure below:

\begin{tabular}{|c|l|c|}
\hline No & \multicolumn{1}{|c|}{$\begin{array}{c}\text { Names of Ghazal Melayu Johor Songs Composer } \\
\text { (Popular) }\end{array}$} & Year \\
\hline 1. & Pak Lomak & 1920 till 1940s \\
\hline 2. & S. Baharom & $1950 \mathrm{~s}$ \\
\hline 3. & Mokhtar Zam Zam & $1960 \mathrm{~s}$ \\
\hline 4. & Ahmad Jusuh & $1970 \mathrm{~s}$ \\
\hline 5. & Mohd Noh Said & $1980 \mathrm{~s}$ \\
\hline 6. & Idris Mohamed & $1990 \mathrm{~s}$ \\
\hline 7. & - & $2000-2010$ \\
\hline 8. & Kamarulzaman Mohamed Karim & $2010-2020$ \\
\hline
\end{tabular}

Figure 2 Names of Ghazal songs composers according to the year

The figure above is as one of the models used to examine the composition of ghazal music happened in every decade. These prominent figures are samples or reference to the development of Ghazal Melayu Johor music composition rarely known to the public. S. Baharom, Mokhtar Zam Zam, Ahmad Jusuh, Mohd Noh Said and Idris Mohamed are the prominent figures who supported the struggles of Pak Lomak's in the creativity of ghazal music composition. They have their own style songs compositions.

Nevertheless, getting the input about the prominent figures who have composed ghazal songs for the year 2000 until current is very difficult. This is due to the fact that the recordings of current ghazal songs are merely repetition of performances from the old songs. Except in 2015 in which a group called GhaMuhyi, was formed by the author himself (Kamarulzaman Mohamed Karim) who was then performing and recording Ghazal Melayu Johor songs with a new style or contemporary. 
INTERNATIONAL JOURNAL OF ACADEMIC RESEARCH IN BUSINESS AND SOCIAL SCIENCES Vol. 10, No. 9, 2020, E-ISSN: 2222-6990 @ 2020 HRMARS

\section{Popular Songs of Ghazal Melayu Johor starting from 1950 until present}

The year 1950s was chosen as the starter in this study because the years marked the beginning of the development of the Ghazal Melayu Johor music very rapidly then it was followed in the 1960s, 1970s and 1980s. These three decades are very significant to the development of Ghazal Melayu Johor music as the benchmark for creative compositions produced. In addition, it is also as a measure of the popularity songs composed based on the frequency of recordings made by many ghazal groups.

The element of popularity in this context is based on the number of recordings available in the form of gramophone record, cassettes and CDs. Each ghazal group who went through the process of recording would be playing similar repertoire in their album recording. It is unconfirmed of the basis for doing that, however, the songwriters admitted that there was an element of popularity in the selection of songs recorded for promotional and marketing purposes. The writer has set three main methods in selecting suitable songs to be used as research materials for this study: (1) the songs were often recorded many times by different ghazal groups, (2) the songs had unique musical characters; and (3) the songs were composed by famous songs composers of the time.

\begin{tabular}{|c|c|c|c|c|c|}
\hline No & Title & Composer & Singer & Group & $\begin{array}{c}\text { Year of } \\
\text { Recording }\end{array}$ \\
\hline 1 & $\begin{array}{l}\text { Bukit } \\
\text { Terih }\end{array}$ & S Baharom Pengail & M Karim & Sri Melati Ghazal J. B & $1980 s$ \\
\hline 2 & $\begin{array}{l}\text { Gunung } \\
\text { Soga }\end{array}$ & Salleh Suradi & $\begin{array}{l}\text { Ayob } \mathrm{Hj} \\
\text { Khdzir }\end{array}$ & $\begin{array}{c}\text { Jalan Dewan Pontian } \\
\text { Ghazal }\end{array}$ & 1980s \\
\hline 3 & $\begin{array}{l}\text { Pucuk } \\
\text { Palas }\end{array}$ & Awang@ Ismail Jusoh & M Karim & Sri Melati Ghazal J.B & 1970s \\
\hline 4 & $\begin{array}{c}\text { Puteri } \\
\text { Menangis }\end{array}$ & Yusof Akil & $\begin{array}{l}\text { Ramlah } \\
\text { Rahim }\end{array}$ & $\begin{array}{c}\text { Ros Tebrau Ghazal J. } \\
\text { Bahru }\end{array}$ & 1980s \\
\hline 5 & $\begin{array}{l}\text { Seruling } \\
\text { Buloh }\end{array}$ & $\begin{array}{c}\text { Johar dari Kg Bahru Jemaah } \\
\text { Ghazal Johor Bharu }\end{array}$ & Adek Esah & $\begin{array}{c}\text { Sri Penambang } \\
\text { Ghazal Muar }\end{array}$ & 1960s \\
\hline 6 & Sri Pati & Johar & $\begin{array}{l}\text { Jaafar } \\
\text { Ismail } \\
\end{array}$ & $\begin{array}{c}\text { Kg Bahru Jemaah } \\
\text { Ghazal Johor Bharu }\end{array}$ & 1960s \\
\hline 7 & Sri Skudai & $\begin{array}{c}\text { Kassim Taib dari Sri } \\
\text { Timbalan Ghazal Johor } \\
\text { Bharu }\end{array}$ & SA Aishah & Sri Melati Ghazal J. B & 1970s \\
\hline 8 & $\begin{array}{c}\text { Nasib } \\
\text { Pengail }\end{array}$ & $\begin{array}{c}\text { S Baharom Pengail/ Ahmad } \\
\text { Keling }\end{array}$ & $\begin{array}{l}\text { Ramlah } \\
\text { Adon }\end{array}$ & $\begin{array}{c}\text { Sri Penambang } \\
\text { Ghazal Muar }\end{array}$ & 1960s \\
\hline 9 & $\begin{array}{l}\text { Lancang } \\
\text { Daik }\end{array}$ & $\begin{array}{l}\text { S Baharom Pengail/ Ahmad } \\
\text { Keling }\end{array}$ & M Karim & Sri Melati Ghazal J. B & 1980s \\
\hline
\end{tabular}

Figure 3 Findings of ghazal songs in the 1950s

Figure 3 above shows the findings of Ghazal Melayu Johor songs composition around the year of 1950s. Around this year, ghazal music was one of the popular folk music that spread throughout the state of Johor. All earliest songs recorded were in the 1960s Based on the recording, Mr. S. Baharom Pengail was the most popular ghazal songs composition in the 1950s. He had composed 
INTERNATIONAL JOURNAL OF ACADEMIC RESEARCH IN BUSINESS AND SOCIAL SCIENCES Vol. 10, No. 9, 2020, E-ISSN: 2222-6990 @ 2020 HRMARS

three songs which had become the phenomenon and the most popular among ghazal musicians, namely Bukit Terih, Nasib Pengail and Lancang Daik.

The similarities in terms of musical in all the songs mentioned above are in the aspects of the form or structure of the songs themselves. The two-part form or so-called binary form is synonymous with traditional ghazal music and that is clearly seen in the songs above. The difference is the way the song is played or the improvisational element based on the virtuosity of the musicians.

\begin{tabular}{|c|c|c|c|c|c|}
\hline No & Title & Composer & Singer & Group & $\begin{array}{c}\text { Years of the } \\
\text { recordings }\end{array}$ \\
\hline 1 & $\begin{array}{c}\text { Ampangan } \\
\text { Kelang }\end{array}$ & $\begin{array}{c}\text { Mokhtar Zam } \\
\text { Zam }\end{array}$ & Ungku Ketty & $\begin{array}{c}\text { Shah Utama } \\
\text { Ghazal Johor } \\
\text { Bharu }\end{array}$ & $1960 \mathrm{~s}$ \\
\hline 2 & $\begin{array}{c}\text { Bukit } \\
\text { Kesenangan }\end{array}$ & $\begin{array}{c}\text { Mokhtar Zam } \\
\text { Zam }\end{array}$ & $\begin{array}{l}\text { A. Samad Bin } \\
\text { Katin }\end{array}$ & $\begin{array}{c}\text { Shah Utama } \\
\text { Ghazal Johor } \\
\text { Bharu }\end{array}$ & $1960 \mathrm{~s}$ \\
\hline 3 & Bukit Melati & $\begin{array}{c}\text { Mokhtar Zam } \\
\text { Zam dari Shah } \\
\text { Utama Ghazal } \\
\text { Johor Bharu }\end{array}$ & M Karim & $\begin{array}{c}\text { Sri Melati } \\
\text { Ghazal J. Bahru }\end{array}$ & $1970 \mathrm{~s}$ \\
\hline 4 & Bunga Raya & $\begin{array}{c}\text { Mokhtar Zam } \\
\text { Zam }\end{array}$ & $\begin{array}{l}\text { Mohd Amin } \\
\text { Bin Mohd }\end{array}$ & $\begin{array}{c}\text { Shah Utama } \\
\text { Ghazal Johor } \\
\text { Bharu }\end{array}$ & 1960s \\
\hline 5 & Che Siti & Atan Buntal & SA Aishah & $\begin{array}{c}\text { Sri Penambang } \\
\text { Ghazal Muar }\end{array}$ & $1960 \mathrm{~s}$ \\
\hline 6 & Dodoi Anak & Ahmad Jusoh & Ahmad Jusoh & $\begin{array}{c}\text { Sri Penambang } \\
\text { Ghazal Muar }\end{array}$ & 1960's \\
\hline 7 & $\begin{array}{c}\text { Kasih } \\
\text { Menumpang }\end{array}$ & $\begin{array}{c}\text { A Wahid Aziz } \\
\text { (Lang Sewah } \\
\text { Ghazal Kota } \\
\text { Tinggi) }\end{array}$ & Maimunah & $\begin{array}{c}\text { Sri Melati } \\
\text { Ghazal J. Bahru }\end{array}$ & $1970 \mathrm{~s}$ \\
\hline 8 & $\begin{array}{c}\text { Kasih } \\
\text { Terpendam }\end{array}$ & Atan Buntal & Rosiah Chik & $\begin{array}{c}\text { Sri Penambang } \\
\text { Ghazal Muar }\end{array}$ & $1960 \mathrm{~s}$ \\
\hline 9 & Kuala Endau & $\begin{array}{c}\text { Mokhtar Zam } \\
\text { Zam }\end{array}$ & $\begin{array}{c}\text { Mokhtar Zam } \\
\text { Zam }\end{array}$ & $\begin{array}{c}\text { Shah Utama } \\
\text { Ghazal Johor } \\
\text { Bharu }\end{array}$ & 1960s \\
\hline 10 & Kuala Skudai & Jaafar Ali & Jaafar Ali & $\begin{array}{c}\text { Setia Jaya } \\
\text { Ghazal Tampoi }\end{array}$ & 1960s \\
\hline 11 & $\begin{array}{c}\text { Laksamana } \\
\text { Bentan }\end{array}$ & $\begin{array}{c}\text { Kassim Taib } \\
\text { dari Sri } \\
\text { Timbalan } \\
\text { Ghazal Johor } \\
\text { Bharu }\end{array}$ & SA Aishah & $\begin{array}{c}\text { Sri Melati } \\
\text { Ghazal Johor } \\
\text { Bahru }\end{array}$ & 1970s \\
\hline 12 & $\begin{array}{l}\text { Mak Ngah } \\
\text { Tersenyum }\end{array}$ & $\begin{array}{c}\text { Atan Buntal } \\
\text { dari Sri }\end{array}$ & Rosiah Chik & $\begin{array}{l}\text { Orkes Ghazal } \\
\text { Fadzil Ahmad }\end{array}$ & $1990 \mathrm{~s}$ \\
\hline
\end{tabular}


INTERNATIONAL JOURNAL OF ACADEMIC RESEARCH IN BUSINESS AND SOCIAL SCIENCES Vol. 10, No. 9, 2020, E-ISSN: 2222-6990 @ 2020 HRMARS

\begin{tabular}{|c|c|c|c|c|c|}
\hline & & $\begin{array}{l}\text { Penambang } \\
\text { Ghazal Muar }\end{array}$ & & & \\
\hline 13 & $\begin{array}{c}\text { Memendam } \\
\text { Rasa }\end{array}$ & $\begin{array}{l}\text { Atan Buntal/ } \\
\text { Penambang (Sri } \\
\text { Penambang } \\
\text { Muar) }\end{array}$ & Rosiah Chik & $\begin{array}{l}\text { Sri Pelangi } \\
\text { Ghazal Muar }\end{array}$ & $1970 \mathrm{~s}$ \\
\hline 14 & Mendung Petang & $\begin{array}{l}\text { Atan Buntal/ } \\
\text { Penambang }\end{array}$ & Maimunah & $\begin{array}{c}\text { Sri Melati } \\
\text { Ghazal Johor } \\
\text { Bahru }\end{array}$ & $1970 s$ \\
\hline 15 & Nasib Jeragan & Atan Buntal & Awang Bakar & Sri Penambang & 1960s \\
\hline 16 & Nasib Stulang & Kassim Taib & Aisah Ahmad & $\begin{array}{c}\text { Sri Timbalan } \\
\text { Ghazal J. Bahru }\end{array}$ & $1960 s$ \\
\hline 17 & $\begin{array}{c}\text { Pembukaan Lang } \\
\text { Sewah - } \\
\text { Mendung Pagi }\end{array}$ & A Wahid Aziz & Rosiah Chik & $\begin{array}{c}\text { Lang Sewah } \\
\text { Ghazal Kota } \\
\text { Tinggi }\end{array}$ & $1960 s$ \\
\hline 18 & Sri Puleh & $\begin{array}{c}\text { Atan Buntal/ } \\
\text { Penambang }\end{array}$ & Rosiah Chik & $\begin{array}{l}\text { Sri Maharani } \\
\text { Ghazal Muar }\end{array}$ & 1980s \\
\hline 19 & $\begin{array}{l}\text { Telok Mahkota/ } \\
\text { Istana Kayangan }\end{array}$ & $\begin{array}{l}\text { Atan Buntal/ } \\
\text { Penambang }\end{array}$ & Rosiah Chik & Sri Penambang & $1960 s$ \\
\hline 20 & Tasik Utara & $\begin{array}{c}\text { Moktar Zam } \\
\text { Zam }\end{array}$ & M Karim & $\begin{array}{c}\text { Sri Melati } \\
\text { Ghazal J. Bahru }\end{array}$ & $1970 s$ \\
\hline
\end{tabular}

Figure 4 Findings of ghazal songs in the 1960s

Figure 4 above shows an increase in the number of compositions of ghazal songs commonly recorded by ghazal groups. In this era, big names emerged that are actively composing new songs which were widely accepted by many groups, namely Mokhtar Zam Zam, Atan Butal, Ahmad Jusuh, Kassim Taib, A. Wahid Aziz and Jaafar Ali. Based on the lists, the works of Mokhtar Zam Zam are most recorded and played. One of his most popular songs played among ghazal musicians is Bukit Kesenangan. 
INTERNATIONAL JOURNAL OF ACADEMIC RESEARCH IN BUSINESS AND SOCIAL SCIENCES Vol. 10, No. 9, 2020, E-ISSN: 2222-6990 @ 2020 HRMARS

\begin{tabular}{|c|c|c|c|c|c|}
\hline No. & Title & Composer & Singer & Group & $\begin{array}{l}\text { Year of } \\
\text { recording }\end{array}$ \\
\hline 1 & $\begin{array}{c}\text { Bayangan } \\
\text { Pelangi }\end{array}$ & Ahmad Jusoh & Zarina Daim & $\begin{array}{l}\text { Sri Maharani } \\
\text { Ghazal Muar }\end{array}$ & 1980s \\
\hline 2 & Bukit Piatu & Ahmad Jusoh & S Fauziah & $\begin{array}{l}\text { Sri Maharani } \\
\text { Ghazal Muar }\end{array}$ & $1970 \mathrm{~s}$ \\
\hline 3 & Bukit Putera & Ahmad Jusoh & Rosiah Chik & $\begin{array}{l}\text { Sri Maharani } \\
\text { Ghazal Muar }\end{array}$ & 1980s \\
\hline 4 & Delima Manis & Ahmad Jusoh & S Fauziah & $\begin{array}{l}\text { Sri Maharani } \\
\text { Ghazal Muar }\end{array}$ & 1970s \\
\hline 5 & $\begin{array}{l}\text { Dendang } \\
\text { Kayangan }\end{array}$ & Atan Ahmad & Orkid Abdullah & $\begin{array}{c}\text { Sri Kenangan } \\
\text { Ghazal Batu } \\
\text { Pahat }\end{array}$ & $1980 \mathrm{~s}$ \\
\hline 6 & Godaan Rindu & A Wahid Aziz & $\begin{array}{c}\text { Maimunah } \\
\text { Mohd }\end{array}$ & $\begin{array}{c}\text { Sri Melati } \\
\text { Ghazal Johor } \\
\text { Bharu }\end{array}$ & $1970 \mathrm{~s}$ \\
\hline 7 & Jiwa Terpendam & $\begin{array}{c}\text { Bachik } \\
\text { Daiman }\end{array}$ & Hafsah Ahmad & $\begin{array}{c}\text { Sri Kukup } \\
\text { Pontian }\end{array}$ & 1970s \\
\hline 8 & Kuala Kesang & Ali Mohd & Rosiah Chik & $\begin{array}{l}\text { Sri Maharani } \\
\text { Ghazal Muar }\end{array}$ & 1980s \\
\hline 9 & $\begin{array}{c}\text { Nasib } \\
\text { Penambang }\end{array}$ & $\begin{array}{c}\text { Mohd Noh } \\
\text { Said }\end{array}$ & M Karim & $\begin{array}{c}\text { Sri Melati } \\
\text { Ghazal Johor } \\
\text { Bharu }\end{array}$ & 1970s \\
\hline 10 & Pulau Kukup & $\begin{array}{c}\text { Ahli Sri Kukup } \\
\text { Ghazal } \\
\text { Pontian }\end{array}$ & Hafsah Ahmad & $\begin{array}{l}\text { Sri Kukup } \\
\text { Pontian }\end{array}$ & 1970s \\
\hline 11 & $\begin{array}{l}\text { Puteri Bintang } \\
\text { Timur }\end{array}$ & A Wahid Aziz & Maimunah & $\begin{array}{c}\text { Sri Melati } \\
\text { Ghazal Johor } \\
\text { Bharu }\end{array}$ & $1970 \mathrm{~s}$ \\
\hline 12 & Selendang Bali & Ahmad Jusoh & Ahmad Jusoh & $\begin{array}{l}\text { Sri Maharani } \\
\text { Ghazal Muar }\end{array}$ & 1970s \\
\hline 13 & Seri Melati & A Wahid Aziz & Maimunah & $\begin{array}{c}\text { Sri Melati } \\
\text { Ghazal Johor } \\
\text { Bharu }\end{array}$ & 1970s \\
\hline 14 & Sri Pelangi & Ahmad Jusoh & Ramlah Adon & $\begin{array}{l}\text { Sri Maharani } \\
\text { Ghazal Muar }\end{array}$ & 1970s \\
\hline 15 & Tangisan Hati & A Wahid Aziz & Aisah Wahid & $\begin{array}{c}\text { Sri Melati } \\
\text { Ghazal Johor } \\
\text { Bharu }\end{array}$ & 1970s \\
\hline 16 & $\begin{array}{c}\text { Tanjong } \\
\text { Penyabong }\end{array}$ & $\begin{array}{c}\text { Atan } \\
\text { Ahmmad }\end{array}$ & M Rosila & $\begin{array}{c}\text { Sri Kenangan } \\
\text { Ghazal Batu } \\
\text { Pahat }\end{array}$ & 1970s \\
\hline
\end{tabular}


INTERNATIONAL JOURNAL OF ACADEMIC RESEARCH IN BUSINESS AND SOCIAL SCIENCES Vol. 10, No. 9, 2020, E-ISSN: 2222-6990 @ 2020 HRMARS

\begin{tabular}{|c|c|c|c|c|c|}
\hline 17 & Tanjung Serindit & $\begin{array}{c}\text { Maziah Md } \\
\text { Shah }\end{array}$ & $\begin{array}{c}\text { Maziah Md } \\
\text { Shah }\end{array}$ & $\begin{array}{c}\text { Kumpulan Bukit } \\
\text { Hampar Ghazal } \\
\text { Segamat }\end{array}$ & 1970s \\
\hline 18 & Tasik Embon & $\begin{array}{c}\text { Mohd Noh } \\
\text { Said }\end{array}$ & M Karim & $\begin{array}{c}\text { Sri Melati } \\
\text { Ghazal Johor } \\
\text { Bharu }\end{array}$ & $1970 \mathrm{~s}$ \\
\hline 19 & Intan Baiduri & A Wahid & M Karim & $\begin{array}{c}\text { Sri Melati } \\
\text { Ghazal Johor } \\
\text { Bharu }\end{array}$ & 1970s \\
\hline
\end{tabular}

Figure 5 Findings of ghazal songs in the 1970s

Figure 5 shows that the composition of ghazal songs has been recorded more and more. This marked as a benchmark for the golden age of Ghazal Melayu Johor music. Many composers appeared at that time such as Ahmad Jusoh, Atan Ahmad, A Wahid Aziz, Bachik Daiman, Mohd Noh Said and Maziah Md Shah. Among them, Ahmad Jusuh was considered one of the well-known figures not only in the composition of ghazal music but also with his courage to do some innovation on ghazal music such as combining it with modern Western music such as jazz. His courageous nature had made many ghazal artists call him 'Pak Godak'. 'Godak' can be connoted as the behavior of people who like to mix things up. 
INTERNATIONAL JOURNAL OF ACADEMIC RESEARCH IN BUSINESS AND SOCIAL SCIENCES Vol. 10, No. 9, 2020, E-ISSN: 2222-6990 @ 2020 HRMARS

\begin{tabular}{|c|c|c|c|c|c|}
\hline No & Title & Composer & Singer & Group & $\begin{array}{c}\text { Year of } \\
\text { Recording }\end{array}$ \\
\hline 1 & $\begin{array}{l}\text { Bandaraya } \\
\text { Bersejarah }\end{array}$ & $\begin{array}{c}\text { Kumpulan Ros } \\
\text { Tebrau Ghazal } \\
\text { Johor Bharu }\end{array}$ & SA Aishah & $\begin{array}{c}\text { Ros Tebrau } \\
\text { Ghazal Johor } \\
\text { Bharu }\end{array}$ & 1980s \\
\hline 2 & Bukit Pedoman & $\begin{array}{c}\text { Kumpulan Ros } \\
\text { Tebrau Ghazal } \\
\text { Johor Bharu }\end{array}$ & Ramlah Rahim & $\begin{array}{c}\text { Ros Tebrau } \\
\text { Ghazal Johor } \\
\text { Bharu }\end{array}$ & $1980 \mathrm{~s}$ \\
\hline 3 & Bumi Bertuah & $\begin{array}{c}\text { Kumpulan Ros } \\
\text { Tebrau Ghazal } \\
\text { Johor Bharu }\end{array}$ & SA Aishah & $\begin{array}{c}\text { Ros Tebrau } \\
\text { Ghazal Johor } \\
\text { Bharu }\end{array}$ & $1980 \mathrm{~s}$ \\
\hline 4 & Derita Hati & Mohd Noh Said & $\begin{array}{c}\text { Kamariah } \\
\text { Mohd }\end{array}$ & $\begin{array}{c}\text { Sri Melati Ghazal } \\
\text { Johor Bharu }\end{array}$ & $1980 \mathrm{~s}$ \\
\hline 5 & Istana Pelangi & Bachik Daiman & Zarina Daim & Sri Saujana Muar & $1980 \mathrm{~s}$ \\
\hline 6 & Kuala Danga & A Wahid Aziz & SA Aishah & $\begin{array}{c}\text { Ros Tebrau } \\
\text { Ghazal Johor } \\
\text { Bharu } \\
\end{array}$ & $1980 \mathrm{~s}$ \\
\hline 7 & Mustika Rose & $\begin{array}{c}\text { Kumpulan Ros } \\
\text { Tebrau Ghazal } \\
\text { Johor Bharu }\end{array}$ & SA Aishah & $\begin{array}{c}\text { Ros Tebrau } \\
\text { Ghazal Johor } \\
\text { Bharu }\end{array}$ & $1980 \mathrm{~s}$ \\
\hline 8 & Nasib Si Buta & $\begin{array}{c}\text { Sri Bahagia } \\
\text { Ghazal Pontian }\end{array}$ & Zainab Mohd & $\begin{array}{c}\text { Kumpulan Sri } \\
\text { Bahagia Ghazal } \\
\text { Pontian }\end{array}$ & $1980 \mathrm{~s}$ \\
\hline 9 & Nilam Delima & Zainal Talib & SA Aishah & $\begin{array}{c}\text { Ros Tebrau } \\
\text { Ghazal Johor } \\
\text { Bharu }\end{array}$ & $1980 \mathrm{~s}$ \\
\hline 10 & Pusaka Melayu & Mohd Noh Said & M Karim & $\begin{array}{c}\text { Sri Melati Ghazal } \\
\text { Johor Bharu }\end{array}$ & $1980 \mathrm{~s}$ \\
\hline 11 & Ratapan Hati & $\begin{array}{c}\text { Kumpulan Ros } \\
\text { Tebrau Ghazal } \\
\text { Johor Bharu }\end{array}$ & SA Aishah & $\begin{array}{c}\text { Ros Tebrau } \\
\text { Ghazal Johor } \\
\text { Bharu }\end{array}$ & $1980 \mathrm{~s}$ \\
\hline 12 & $\begin{array}{c}\text { Teluk } \\
\text { Cempedak }\end{array}$ & A Wahid Aziz & SA Aishah & $\begin{array}{c}\text { Ros Tebrau } \\
\text { Ghazal Johor } \\
\text { Bharu }\end{array}$ & $1980 \mathrm{~s}$ \\
\hline 13 & Madu Hati & Atan Ahmad & $\begin{array}{c}\text { Orkid } \\
\text { Abdullah }\end{array}$ & $\begin{array}{c}\text { Sri Kenangan } \\
\text { Ghazal Batu } \\
\text { Pahat }\end{array}$ & $1980 \mathrm{~s}$ \\
\hline
\end{tabular}

Figure 6 Findings of ghazal songs in the 1980s

Figure 6 above shows a slight decrease in the new songs recording activities of Ghazal Melayu Johor. Although there are new names in the composition of ghazal songs such as Mohd Noh Said, A. Wahid Aziz, Zainal Talib and Atan Ahmad, the number of new songs is very difficult to identify. Thus, songs written by Mohd Noh as the leader for Seri Melati Ghazal from Johor Bahru were among the songs played frequently until now such as Derita Hati and Pusaka Melayu. 
INTERNATIONAL JOURNAL OF ACADEMIC RESEARCH IN BUSINESS AND SOCIAL SCIENCES Vol. 10, No. 9, 2020, E-ISSN: 2222-6990 @ 2020 HRMARS

\begin{tabular}{|c|c|c|c|c|c|}
\hline No & Title & Composer & Singer & Group & $\begin{array}{c}\text { Year of } \\
\text { Recording }\end{array}$ \\
\hline 1 & Mega Sari & Abu Shah Dolah & Subari Palil & Sri Pelangi & 1990s \\
\hline 2 & $\begin{array}{c}\text { Bukit } \\
\text { Kepong }\end{array}$ & Idris Mohamed & Abdul Rahman & $\begin{array}{c}\text { Yayasan Warisan } \\
\text { Johor }\end{array}$ & $1990 \mathrm{~s}$ \\
\hline
\end{tabular}

Figure 7 Findings of ghazal songs in the 1990s

Figure 7 above shows that the recording activities for ghazal were no longer focused on newly composed songs, but more on repetition of recordings on old ghazal songs. There were only two songs said to be popular among ghazal artists, which is Mega Sari composed by Abu Shah Dolah and Bukit Kepong composed by Idris Mohamed. Bukit Kepong was the most popular song at that time in which new ghazal songs with the theme of patriotism were often accepted in recordings and official performances by Yayasan Warisan Johor. Idris Mohamed was a respected figure as well as the Music Director, Music Performance Division, Johor Heritage Foundation. He contributed a lot to the development of ghazal music and one of the most important contributions was to organize a performance program entitled 'Ghazal Concert' in 2000.

The study also discovered that no findings were revealed for newly composed songs between the years 2000 to 2010. The compositions of new songs for Ghazal Melayu Johor were put on hold over a decade and recording activities and performances were focused entirely on the repetition of old songs. This fact gave an impression that in this decade, Ghazal Melayu Johor music received less attention among local communities. As a result, this music only lived by the repetition of old songs.

\begin{tabular}{|c|c|c|c|c|c|}
\hline No & Title & Composer & Singer & Group & $\begin{array}{c}\text { Year of } \\
\text { Recording }\end{array}$ \\
\hline 1 & Matahari & $\begin{array}{c}\text { Kamarulzaman } \\
\text { Mohamed } \\
\text { Karim }\end{array}$ & $\begin{array}{c}\text { Rojer dan } \\
\text { Zuraidah }\end{array}$ & GhaMuhyi & 2014 \\
\hline 2 & $\begin{array}{c}\text { Telunjuk Silir } \\
\text { Sirat }\end{array}$ & $\begin{array}{c}\text { Kamarulzaman } \\
\text { Mohamed } \\
\text { Karim }\end{array}$ & Asmidar & GhaMuhyi & 2014 \\
\hline 3 & Seri Langit & $\begin{array}{c}\text { Kamarulzaman } \\
\text { Mohamed } \\
\text { Karim }\end{array}$ & Azizul Haqim & GhaMuhyi & 2014 \\
\hline 4 & Bunga & $\begin{array}{c}\text { Kamarulzaman } \\
\text { Mohamed } \\
\text { Karim }\end{array}$ & $\begin{array}{c}\text { Nil } \\
\text { (Instrumental) }\end{array}$ & GhaMuhyi & 2014 \\
\hline
\end{tabular}

Figure 8 Findings of ghazal songs in 2010 until present

Figure 8 shows the activities of composing new ghazal songs started again. Unfortunately, only one group dominated this activity, which was GhaMuhyi, led by the author himself and established in 2014. GhaMuhyi is a group which combines many active young traditional music activists in the Klang Valley with a fresh and intricate new musical expression. 
INTERNATIONAL JOURNAL OF ACADEMIC RESEARCH IN BUSINESS AND SOCIAL SCIENCES Vol. 10, No. 9, 2020, E-ISSN: 2222-6990 @ 2020 HRMARS

\section{Conclusion and Suggestions}

The results revealed that the effect of Ghazal Melayu Johor song compositions were more likely to use the inspiration based on themes of the universe and humanity. This is especially evident in the lyrics used originated from the structure of a poem which consists of the 'hint' part expressed on themes of the universe and the 'meaning' part expressed on themes of humanity. Secondly, the composition of elements other than the lyrics are more inspired by the binary form also affected by the form of Malay poems.

In addition, the style of Ghazal Melayu Johor music composition did not show many significant changes. The traditional idioms introduced by Pak Lomak were followed by the next GMJ music composers. However, starting from 2014, GMJ's music composition styles have undergone a drastic change with the formation of the ghazal group GhaMuhyi. The group has successfully contributed several new repertoires which give new path to GMJ's traditional music idioms that are rarely developed in music compositions. In addition, this group has also succeeded in creating new idioms combined with GMJ traditional music idioms to create a new style.

Based on the whole study as well, it was discovered that the development of GMJ music composition has deteriorated because no composition of new songs since 1990s. Activists were more interested in playing existing works, especially popular GMJ songs such as Seri Mersing, Pak Ngah Balik and Penawar Rindu. This reality is very worrying if it continues for a longer period of time. Interests and the composition abilities have also begun to decrease among young GMJ music activists.

Efforts to increase the collection of GMJ music works need to be continued. The government, through its official broadcasting bodies such as RTM and Radio Klasik FM, needs to be more active in highlighting programs that encourage the composition of traditional music such as GMJ and not just focusing on performances and competitions which only use traditional repertoire. Non-governmental organizations (NGOs) need to be more courageous in organizing programs that can develop awareness of artistic creativity among the community, especially on this traditional art.

\section{Acknowledgement}

This research is funded by Special Grant Scheme (Fundamental) (2017-0208-107-01)/ Skim Geran Penyelidikan Khas (Fundamental) from Universiti Pendidikan Sultan Idris with the total amount of RM10,000.00.

\section{References}

Karim, K. M. (2014). GhaMuhyi. (Unpublished doctoral dissertation). Institut Seni Indonesia Surakarta, Indonesia.

Kanda, K. C. (1998). Masterpieces of Urdu Ghazal: From $17^{\text {th }}$ to $20^{\text {th }}$ Century. New Delhi: Sterling Publisher Pvt. Ltd.

Dewan Bahasa dan Pustaka. (2017). Inspirasi: In prpm.dbp.gov.my dictionary. Retrieved from https://prpm.dbp.gov.my/Cari1?keyword=inspirasi+\&d=243192\&

Machfrida, L. (1998). Kajian Muzik Ghazal Melayu. Johor Bahru: Yayasan Warisan Johor.

Al Mudra, M. (2008). Redefinisi Melayu. Yogyakarta: Balai Kajian dan Pengembangan Budaya Melayu. Nasuruddin, M. G. (1991). Muzik Melayu Tradisi. Kuala Lumpur: Dewan Bahasa \& Pustaka. 
INTERNATIONAL JOURNAL OF ACADEMIC RESEARCH IN BUSINESS AND SOCIAL SCIENCES Vol. 10, No. 9, 2020, E-ISSN: 2222-6990 @ 2020 HRMARS

Sumardjo, J. (2000). Filsafat Seni. Bandung: Penerbit ITB.

Tahir, U. M. Z. (1998). Perkembangan lagu-lagu Ghazal Melayu Johor. Jurnal Warisan Johor, Jilid II, 143-153. 